\title{
River Basin Modelling for Optimum Water Usage: Uma Oya Downstream Development Area
}

\author{
K.P.S.T. Pathirana, R.M.A. De S. Thanapathy and K.D.W. Nandalal
}

\begin{abstract}
Water is a basic need of all living beings and the management of water in an optimum manner has therefore now received worldwide attention. This optimum management of water is achieved through the construction of reservoir systems and their optimal operation. This paper presents a simulation study carried out using Water Evaluation and Planning System (WEAP) software at the proposed Uma Oya Downstream Development Project in the Kirindi Oya basin in Sri Lanka. To investigate the impact of the proposed system, one model was developed for the existing system and another for the proposed system. Crop water requirements and irrigation schedules for three climatic conditions were determined using CROPWAT software. Climatic conditions were those of the years which received rainfalls with $20 \%, 50 \%$ and $80 \%$ probability of exceedance representing wet, normal and dry years respectively. Daily rainfall, runoff and other meteorological data were the information collected for the study. Availability of water for the irrigation of existing and newly proposed areas was ascertained from the model. Optimal operation patterns were developed for the newly built Alikota Ara and Kuda Oya reservoirs and the enlarged Handapanagala reservoir for different climatic conditions. Results indicated that even when the system is operating in accordance with optimum operating rules, there can be supply deficits. A study was made on the system performance with reduced irrigable areas and different crop types which were observed to bring in reduced deficits.
\end{abstract}

Keywords: Reservoir system simulation, Crop water estimation, Reservoir operating rules

\section{Introduction}

The availability of land and water resources is vital for the agriculture of any country. Water being a scarce resource and a commodity that will have an exponential demand with the growth of the population, it is important to use this resource in the most effective and efficient manner. To achieve this objective, the Government of Sri Lanka planned and implemented a major multi-purpose water resources development project to divert water from Uma Oya to Kirindi Oya, generating hydro-energy at the same time. Water that is diverted will be available for irrigation in the Kirindi Oya basin located in the South-East Dry Zone of the country. This project named "Uma Oya Downstream Development Project" includes the construction of two new reservoirs, raising an existing dam and the construction of a network of irrigation canals for improving the irrigation facilities in the area.

The project envisaged, is a very complex one and the planning and management of such a project demands the use of systems analysis techniques. The systems analysis techniques available for such tasks could be broadly categorised into two types: optimization methods and simulations. Although optimization techniques can provide the best solution, they will need many simplifications, which may affect the real situation. In contrast, simulation models though not guaranteeing the best solution may represent the actual situation and will thus be acceptable to many. It has to be noted that simulation addresses "what and if" questions, while optimization addresses "what should be" type of questions [1].

Simulation is a process of mimicking the dynamic behaviour of systems over time [2]. The simulation models adopted in reservoir operation and management are generally based on reservoir continuity or mass equation, and represent the hydrological behaviour of the systems considering inflows and other operating conditions [3]. It has been observed that optimization techniques have high efficiency when coupled with simulation modelling and that they offer better results in handling reservoir management problems.

\footnotetext{
Miss. K.P.S.T. Pathirana, Student Member of IESL, B.Sc.Eng.(Hons), Lanka Hydraulic Institute, Katubedda, Moratuwa.Email:kpsachi.25@yahoo.com

Miss. R.M.A. De S. Thanapathy, Student Member of IESL, B.Sc.Eng.(Hons), Ceylex Engineering (Pvt) Ltd, Colombo 02. Email:minoli.thanapathy@gmail.com

Eng. (Prof.) K.D.W. Nandalal, Int.PEng.(SL), C.Eng., FIE(Sri Lanka), B.Sc.Eng.(Hons), MEng(AIT), Ph.D. (The Netherlands), Senior Professor, Department of Civil Engineering, University of Peradeniya.

Email:kdwn@pdn.ac.lk
} 
However, the results obtained through these optimization-simulation models may not be practicable due to social and other issues. The simulation models allow a more detailed and faithful representation of a real world system performance than the optimization models [3]. Therefore in this study, a simulation model has been used.

Water Evaluation and Planning System (WEAP) software has been used in this study. It has a large number of applications. In order to reduce the stress on water, the Jordan valley has been modeled for different climatic conditions using WEAP software. The impact of changes on cropping patterns has also been studied [4]. WEAP software has been used to evaluate and analyse the existing water balance and expected future water resource management scenarios by considering different operating policies on the efficient management of desalination of sea water and inter-basin transfers [5]. The usefulness of WEAP for integrated water resource management in the Gaza strip which has a semi-arid Mediterranean climate has also been studied. In that area, the main water resource for domestic, industrial and agricultural use is groundwater supplemented by water imported from Israel and storm water that has been collected [6].

CROPWAT is an irrigation management and planning software, which facilitates the estimation of crop evapotranspiration, irrigation scheduling and agricultural water requirements with different cropping patterns for irrigation planning. The use of the CROPWAT model to calculate crop water requirement has been investigated by many [7]. The CROPWAT model has been used to simulate various options for water supply and irrigation management and to study yield losses under irrigated and rain fed conditions [8].

In this study, WEAP software was used for modelling the Uma Oya Downstream Development Project while CROPWAT programme was used for the estimation of crop water requirements and different irrigation schedules. The objective of the study was confined to demonstrating the use of the above two models at the planning stage of a water resources development project and it has to be stressed here that this study was not a feasibility study of any project whatsoever.

\section{Study Area}

\subsection{Uma Oya Multipurpose Development Project}

The Uma Oya Multi-Purpose Development Project, which is presently under construction, intends to divert about $145 \times 10^{6} \mathrm{~m}^{3} / \mathrm{yr}$ from the Uma Oya basin in the wet zone to the Kirindi Oya basin in the dry zone, generating electrical energy during the process. Two reservoirs built on the two main tributaries of the Uma Oya, viz., Dalgolla Oya and Mahathotilla Oya at Puhulpola and Dyraaba respectively, are supposed to store and divert water through a series of tunnels to an underground hydropower plant built at Randeniya which would finally release water to Alikota Ara, a tributary of the Kirindi Oya.

It is proposed to use water reaching Kirindi Oya to enhance agricultural activities in the basin and to supply water to meet industrial and drinking water requirements, through a development project called "Uma Oya Downstream Development Project."

\subsection{Uma Oya Downstream Development Project}

Water transferred to Alikota Ara after generating hydro-power will finally reach Kirindi Oya. There are presently a few structures within the area that have to be developed, viz., Handapanagala reservoir, Handapanagala anicut and Ussella anicut to provide irrigation water to the ongoing irrigation activities in the area. The proposed plan is to enlarge the existing Handapanagala reservoir and to build two new reservoirs on Alikota Ara and Kuda Oya along with a canal system to enhance the water supply to the existing irrigation areas and also to proposed new irrigation areas. The stream network of the Kirindi Oya and the locations where reservoirs are to be constructed are shown in Figure 1. It also shows two locations where the stream flows are gauged by the Irrigation Department. 


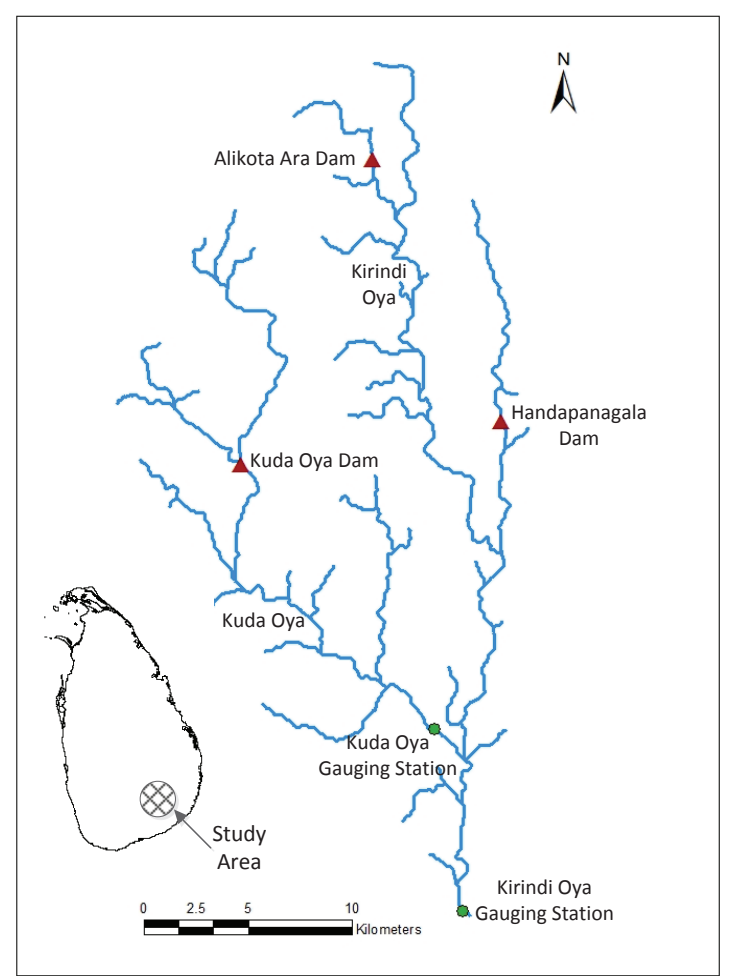

Figure 1 - River network of the Kirindi Oya

Figure 2 shows the schematic diagram of the proposed Uma Oya Downstream Development Project.

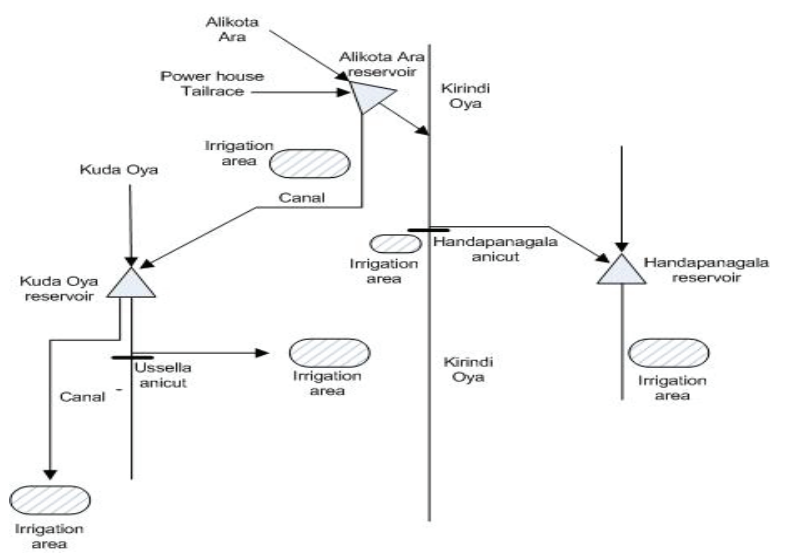

Figure 2 - Schematic diagram of the proposed Uma Oya Downstream Development Project

Water coming from the Randeniya power plant is to be regulated by a reservoir to be built on the Alikota Ara. Its storage capacity would be $6.5 \times 10^{6} \mathrm{~m}^{3}$. A $35 \mathrm{~km}$ long canal will carry water from the Alikota Ara reservoir to a reservoir to be built on Kuda Oya. This canal will also feed the existing and new irrigation areas located along the canal. The Kuda Oya reservoir will have a capacity of $33.4 \times 10^{6} \mathrm{~m}^{3}$ and there will be a canal leading from it on the right bank feeding new irrigable areas. Water stored in the Kuda Oya reservoir will be available for cultivations along the Kuda Oya right bank main canal coming under the Ussella anicut scheme located downstream of the Kuda Oya reservoir on Kuda Oya. Alikota Ara also would release water to Kirindi Oya which will be picked up at the Handapanagala anicut and stored in the Handapanagala reservoir. The left bank and right bank main canals of the Handapanagala reservoir which would have a capacity $16.5 \times 10^{6} \mathrm{~m}^{3}$ will feed many of the existing and new irrigation areas directly as well as through the existing minor irrigation tanks in the area. Water spilling over the Handapanagala anicut and the Ussella anicut and the drainage water from the irrigation areas will flow into Lunugamvehera reservoir through Kirindi Oya. This additional water reaching the Lunugamvehera reservoir will be available for the development activities in Hambantota.

\section{Methodology}

\subsection{Data Collection}

The WEAP software based system simulation model requires monthly stream flow data, existing and proposed irrigation areas and irrigation demands and the characteristics of the existing and proposed reservoirs while the CROPWAT programme needs rainfall, minimum and maximum temperatures, relative humidity, sunshine hours and wind velocity at daily time steps.

Kirindi Oya flow data at Wellawaya and Thanamalwila gauging stations and Kuda Oya flow data at the Kuda Oya gauging station were collected from the Department of Irrigation. There are three main rainfall gauging stations located within the study area. They are at Handapanagala, Thanamalwila and Wellawaya. Thanamalwila gauging station from among the three was selected to collect rainfall data for the study which were obtained from the Department of Meteorology. Climatic data which were needed for the CROPWAT programme were obtained from the data recorded at the Agunakolapalassa weather station, the weather station closest to the study area, through the Natural Resources Management Centre of the Department of Agriculture. The station is within the same climatic zone as the study area. 
The Uma Oya diversions reaching Alikota Ara were obtained from the Technical Pre-feasibility Study of FARAB [9] while the details of the reservoirs and irrigation areas were obtained from a report on the Uma Oya Multi-purpose Development Project of the Irrigation Department [10]. The details of the soil were obtained from the soil map of the country.

Based on the available data, a period of 15 years spanning from 2000 to 2014 was selected as the period of analysis. As Uma Oya diversions were available only up to 2008 , the latest 8 -year flow values available were repeated for the period from 2008 to 2014.

\subsection{CROPWAT Programme}

The CROPWAT (Ver 8.0) computer programme has been developed by FAO for the calculation of crop requirements and irrigation requirements based on the type of soil, climate and crop data. The CROPWAT program allows the development of irrigation schedules for different management conditions and the calculation of the scheme water supply for varying crop patterns.

Crop water requirements were calculated for four different rainfall scenarios. They were years with rainfalls of $20 \%, 50 \%$ and $80 \%$ probability of exceedance, representing a wet year, normal year and dry year respectively.

Irrigation requirements were calculated for the Yala season (mid-March - early May) and Maha season (mid-Sept/ Oct - late Jan/Feb) for the above four cases. Thereafter, cropping calendars were shifted forward and backward by two weeks for all the above four cases and crop water requirements estimated. Different crops have different water demands. In the study, replacement of paddy with chilli in a part of the irrigable area was studied to estimate the irrigation water requirements of paddy and chilli.

\subsection{WEAP Software}

Water Evaluation and Planning System (WEAP) software is a tool used for integrated water resources planning in the allocation of limited water resources among agricultural, municipal and environmental users by integrating supply, demand, water quality and ecological considerations. WEAP software was used to model the proposed Uma Oya Downstream Development System to investigate different management scenarios with the aim of using water optimally. In this study, both the existing system and the proposed system were modelled.

\section{Analysis and Results}

\subsection{Four Rainfall Scenarios}

The three rainfall scenarios were determined based on the effective rainfall over the area. Effective rainfall is used to account for losses due to surface runoff and deep percolation. After studying the three methods: (i)Fixed percentage of rainfall, (ii) Dependable rain (empirical form), and (iii) USDA soil conservation method, it was decided to use the third method for the estimation of the effective rainfall as it resulted in a rainfall close to $75 \%$ of the total rainfall which is acceptable both practically and according to the literature.

Thereafter using the selected method, the annual effective rainfall was calculated for each year and ranked in the descending order. A wet year has a rainfall with a $20 \%$ probability of exceedance. Similarly, a dry year and a normal year were also selected.

Based on the data available for the period 20002015, the following years with the annual rainfalls indicated, were found to have different scenarios:

$\begin{array}{lll}\text { Wet year } & 2000 & 1428 \mathrm{~mm} \\ \text { Dry year } & 2002 & 1245 \mathrm{~mm} \\ \text { Normal year } & 2006 & 1329 \mathrm{~mm}\end{array}$

\subsection{Crop Water Requirements}

Crop water requirements were calculated for each season of the three years. Table 1 presents the irrigation water requirements per season for different planting dates estimated using the CROPWAT programme. The water requirements are for the whole season.

Considering the above observations and the practical difficulties faced, crop calendars given in Table 2 were selected as being most beneficial for the study.

\subsection{WEAP Based Simulation}

Two WEAP software based simulation models were created: (i) model for the water resources 
system existing at present, and (ii) model for the proposed water resources system.

Table 1 - Irrigation water requirements in $\mathbf{m m}$

\begin{tabular}{|c|c|c|c|c|}
\hline & Planting Date & $\begin{array}{l}\text { Wet } \\
\text { year }\end{array}$ & $\begin{array}{l}\text { Dry } \\
\text { year }\end{array}$ & $\begin{array}{c}\text { Normal } \\
\text { year }\end{array}$ \\
\hline \multirow{7}{*}{$\frac{\text { I }}{\sum^{\pi}}$} & 01 August & 538 & 692 & 543 \\
\hline & 15 August & 434 & - & 481 \\
\hline & 01 September & 439 & 570 & 412 \\
\hline & 15 September & 411 & 549 & 361 \\
\hline & 01 October & 451 & 547 & 266 \\
\hline & 15 October & - & 520 & - \\
\hline & 01 November & - & 483 & - \\
\hline \multirow{8}{*}{$\frac{\pi}{\pi}$} & 01 February & 392 & 662 & 514 \\
\hline & 15 February & 403 & 643 & 585 \\
\hline & 01 March & 472 & 661 & 609 \\
\hline & 15 March & 545 & 656 & 633 \\
\hline & 01 April & 635 & 662 & 650 \\
\hline & 15 April & -- & 639 & - \\
\hline & 01 May & - & 712 & - \\
\hline & 15 May & - & 685 & - \\
\hline
\end{tabular}

Table 2 - Selected crop calendars

\begin{tabular}{|c|l|l|l|l|}
\hline \multirow{2}{*}{ Yala } & Wet year & 01 February & to & 16 May \\
& Dry year & 15 May & to & 27 August \\
\cline { 2 - 5 } & Normal year & 01 February & to & 16 May \\
\hline \multirow{3}{*}{ Maha } & Wet year & 15 August & to & 27 December \\
\cline { 2 - 5 } & Dry year & 01 November & to & 13 January \\
\cline { 2 - 5 } & Normal year & 15 August & to & 27 December \\
\hline
\end{tabular}

\section{Model for the Exiting System}

This model comprises of the present Handapanagala reservoir, Handapanagala anicut, Ussella anicut, a network of canals and the existing irrigation areas. The present irrigation area is 1403 ha in total. The model uses only water available within the basin. This model will result in business as usual and the results will be used to compare and evaluate the improvements in the proposed system.

Stream flow records available at the Kuda Oya and the Kirindi Oya gauging stations shown in Figure 1 were transferred to the required locations using catchment area ratios. This was possible since hydro-meteorological conditions did not vary much within the study area. The present Handapanagala reservoir has a live storage capacity of $12.0 \times 10^{6} \mathrm{~m}^{3}$.

\section{Model for the Proposed System}

The proposed water resources system is shown in Figure 2. The Handapanagala reservoir is enlarged to have a storage capacity of $16.5 \times 10^{6} \mathrm{~m}^{3}$. The Alikota Ara reservoir with a capacity of $6.5 \times 10^{6} \mathrm{~m}^{3}$ and the Kuda Oya reservoir with a capacity of $33.4 \times 10^{6} \mathrm{~m}^{3}$ are added to the system.

The proposed system is expected to provide a reliable supply of water for the existing irrigation system. The system is also expected to irrigate an additional area. The details of the irrigation areas are given in Table 3.

Table 3 - Existing and proposed irrigation

\begin{tabular}{|l|r|r|}
\hline \multicolumn{1}{|c|}{ Irrigation Areas } & \multicolumn{2}{c}{ Area (ha) } \\
\cline { 2 - 3 } & Existing & Proposed \\
\hline Between Alikota Ara and Kuda Oya reservoirs & 637.9 & 623.5 \\
\hline Downstream of Kuda Oya reservoir & & \\
\hline \multicolumn{1}{|c|}{ Kuda Oya Right Bank Main canal } & & 663.0 \\
\hline Ussella anicut & 110.2 & 827.0 \\
\hline Handapanagala anicut & 15.1 & 750.0 \\
\hline Handapanagala Left Bank Main canal & 124.9 & 1593.0 \\
\hline TOTAL & 888.1 & 4456.5 \\
\hline
\end{tabular}

\subsection{Comparison of Unmet Demands when only Paddy is grown}

\section{Performance during a Wet Year}

Figure 3 compares the unmet demands in the existing system and the proposed system during a wet year. The demands are for the total irrigation area inclusive of both existing and proposed areas.

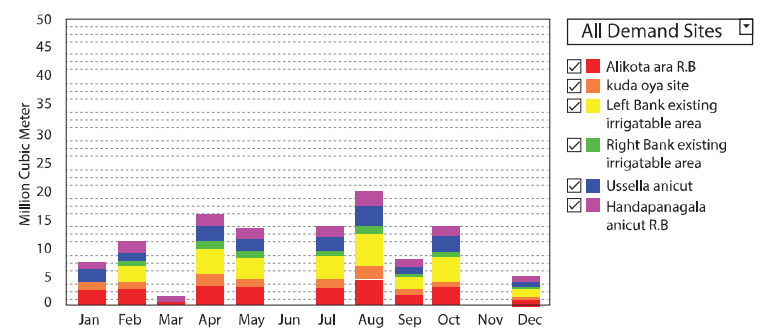

(a) Unmet demands in the present system

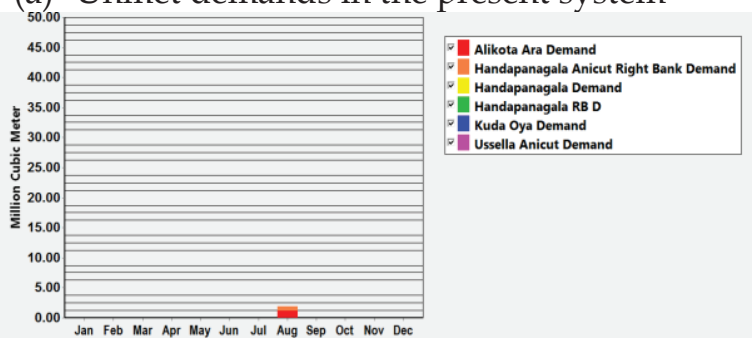

(b) Unmet demands in the proposed system

Figure 3 - Unmet demands in a wet year 


\section{Performance during a Dry Year}

Similarly for the dry year, the unmet demands related to the model of the existing system with proposed areas and the model of the proposed system are shown in Figure 4.

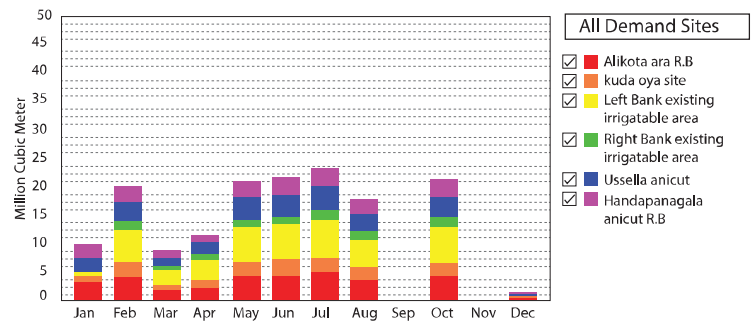

(a) Unmet demands in the present system

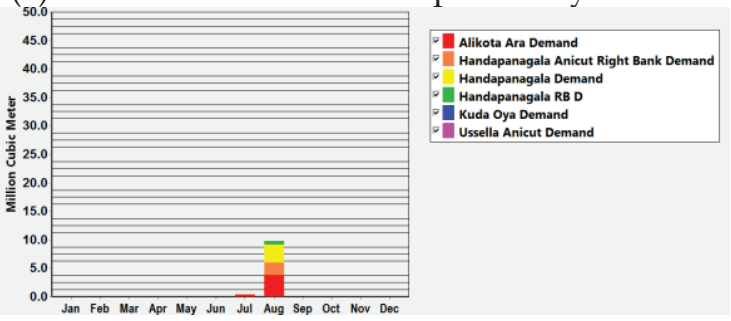

(b) Unmet demands in the proposed system

\section{Figure 4 - Unmet demands in the dry year}

\section{Performance during a Normal Year}

The unmet demands of the normal year are shown in Figure 5 for both the existing and the proposed system.

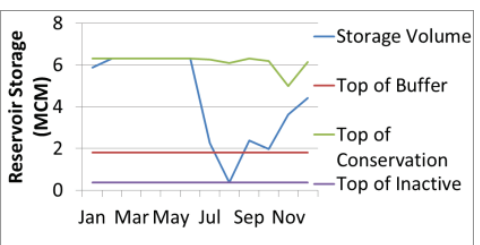

(a) Wet year

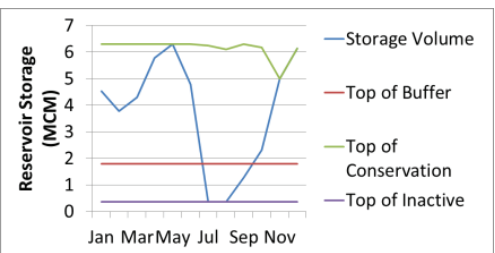

(b) Dry year
Figure 6 - AlikotaAra reservoir operating rules

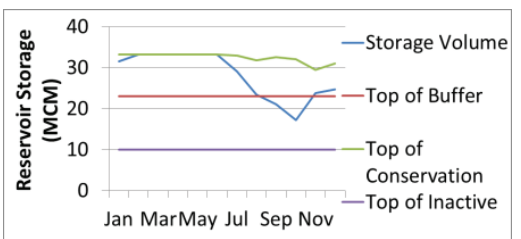

(a) Wet year

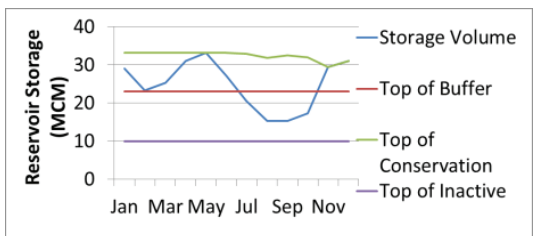

(b) Dry year
Figure 7 - KudaOya reservoir operating rules

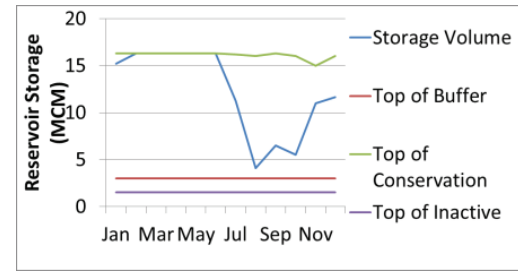

(a) Wet year

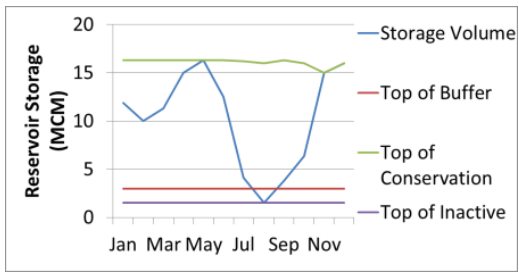

(b) Dry year

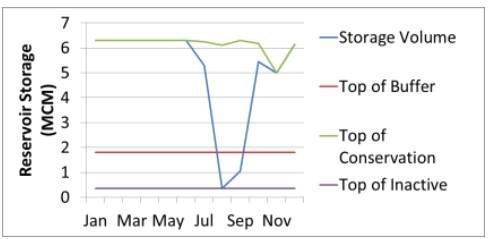

(c) Normal year
All Demand Sites 6 Alikota ara R.B
kuda oya site $\begin{array}{ll}\square & \text { kuda oya site } \\ \square & \text { Left Bank existing }\end{array}$

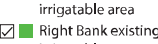
$\square$ Ussella anicut

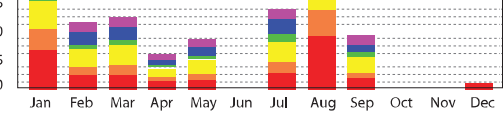

nicut R.B

(a) Unmet demands in the present system

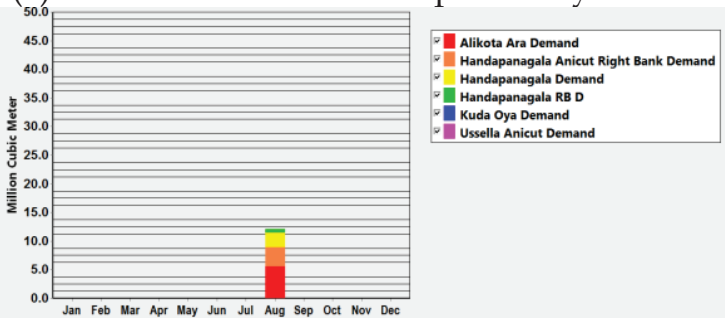

(b) Unmet demands in the proposed system

Figure 5 - Unmet demands in the normal year

\subsection{Reservoir Operating Rules}

Based on a large number of system simulations done by varying the operating pattern, the most suitable operational policies for the three reservoirs were derived. These optimum operation patterns obtained for different climatic conditions, that is for a wet year, dry year and normal year, are presented in Figures 6 through 8.

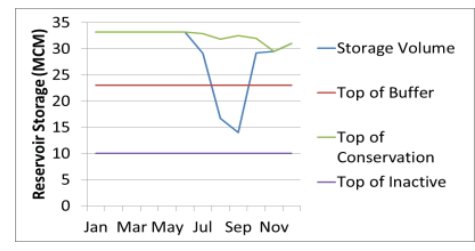

(c) Normal year

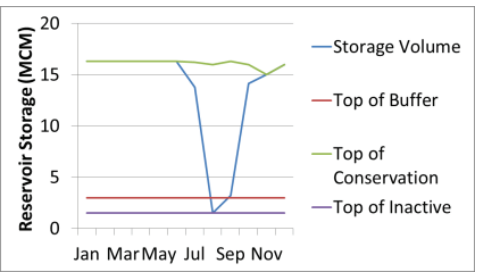

(c) Normal year

Figure 8 - Handapanagala reservoir operating rules 
These optimum operating rules did not meet the irrigation demands completely. The insufficiency of Uma Oya diversions towards Kirindi Oya during the months when water is mostly needed, is a major reason for this behaviour. Therefore, several other alternatives that could be adopted to reduce the number of unmet demands were investigated. The alternatives studied are:

i. reduction of the proposed irrigation areas,

ii. cultivation of chilli along with paddy during one season of the year, and

iii. raising the dam of the Handapanagala reservoir to increase the volume of water stored.

\subsection{Reducing the Proposed Irrigation Areas}

For each dry year, wet year and normal year, unmet demands were found in Alikota Ara and Handapanagala areas. The reason is due to the large increase in the extent of the areas: an increase of $98 \%$ in Alikota Ara and $1275 \%$ in the Handapanagala left bank. Therefore, the proposed areas of Alikota Ara and Handapanagala were reduced by $30 \%, 40 \%$ and $50 \%$ and analysed.

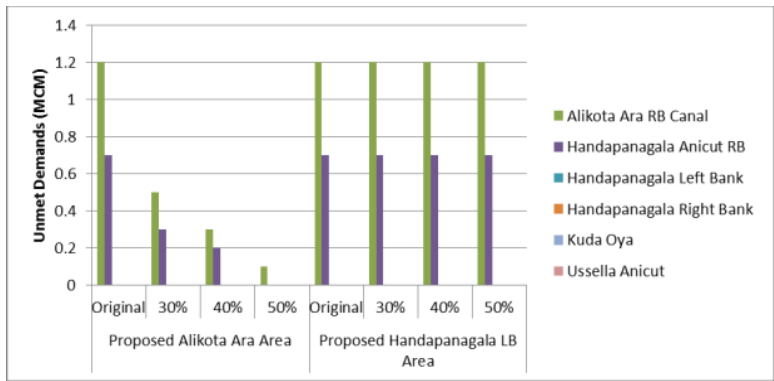

Figure 9 - Unmet demands when the area is reduced during a wet year

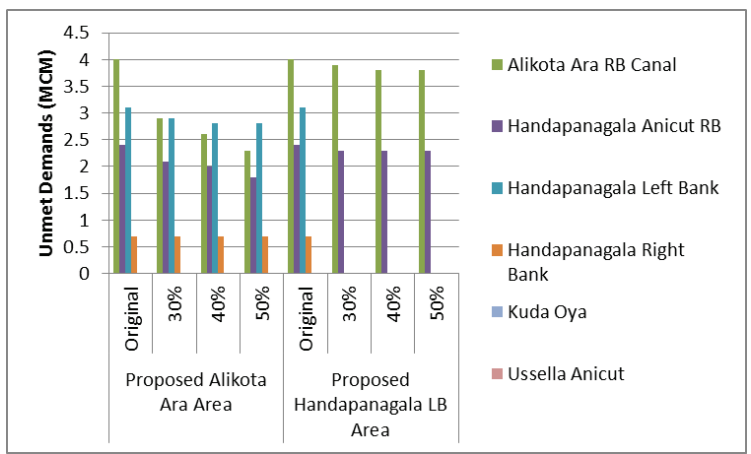

Figure 10 - Unmet demands when the area is reduced during a dry year

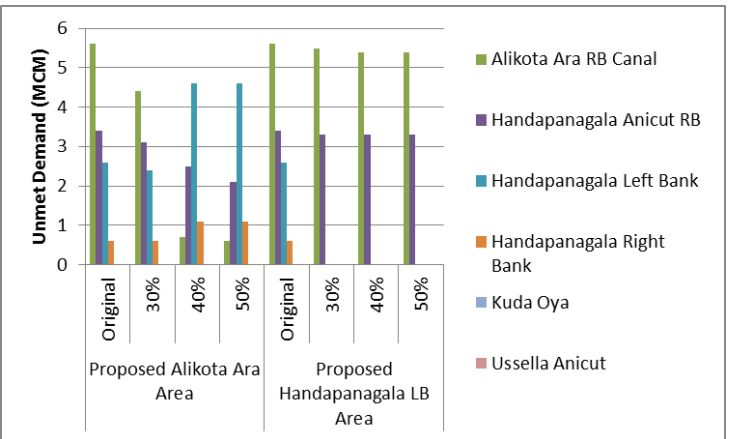

Figure 11 - Unmet demands when the area is reduced during a normal year

\subsection{Cultivating Chilli along with Paddy during One Season of the Year}

The replacement of paddy with chilli was carried out in steps of $40 \%$ and $50 \%$ in the proposed areas in the Alikota Ara and Handapanagala since they showed the highest number of unmet demands. The results obtained are shown below.

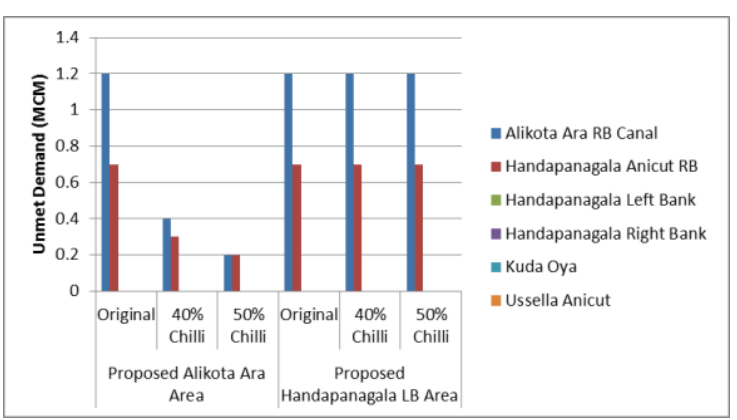

Figure 12 - Unmet demands when Chili is planted in a wet year

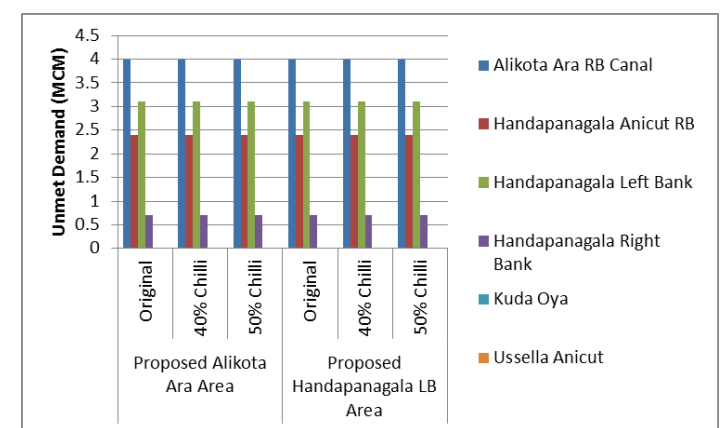

Figure 13 - Unmet demands when Chili is planted in a dry year 


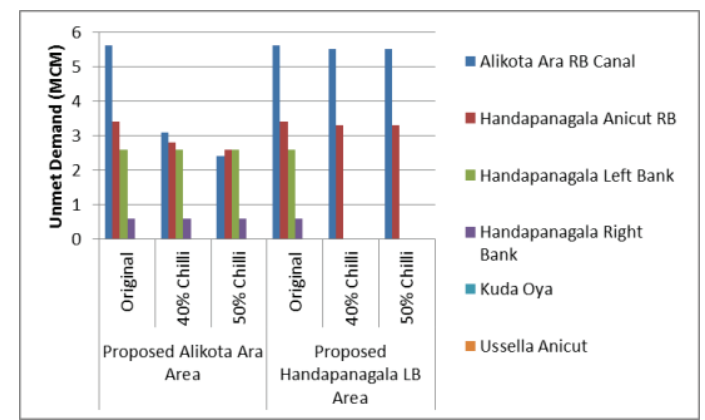

Figure 14 - Unmet demands when Chili is planted in a normal year

\subsection{Raising of the Handapanagala Reservoir Capacity}

When irrigation areas are compared, it could be seen that the number of demands catered to by Handapanagala reservoir was increased by about 3 times as compared to the existing areas. Due to this reason, during the analysis of the proposed model, a storage volume of 16.5 MCM was found insufficient to cater to the full demand. Therefore, an analysis was carried out by increasing the Handapanagala reservoir capacity. Figure 15 gives the results when the Handapanagala reservoir capacity is increased to $18.5 \mathrm{MCM}$ and $20.5 \mathrm{MCM}$ in all three types of years.

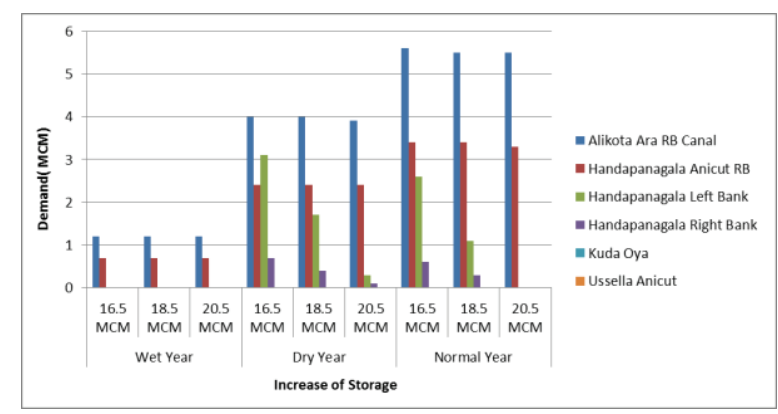

Figure 15 - Unmet demands when the Handapanagala reservoir capacity is increased

\section{Conclusions}

Even after the addition of Alikota Ara and Kuda Oya reservoirs to the system and the enlargement of the Handapanagala reservoir, there were still unmet demands. Increasing the storage capacity of the Handapanagala reservoir resulted in an improvement in the system reliability.

When the extent of the irrigation areas in Alikota Ara was reduced, the number of unmet demands also got reduced, indicating that the amount of diverted water was sufficient to cater to a part of the proposed areas. However, a reduction in the extent of the Handapanagala irrigation areas did not result in any significant reduction in the number of unmet demands which indicates that the amount of diverted water was not sufficient to cater to the proposed areas at all. This may be due to the increase in the irrigation areas in Handapanagala by more than $1000 \%$ whereas the tank capacity of Handapanagala has been increased only by $9.33 \mathrm{MCM}$ to cater to the above mentioned large increase in the extent of the areas.

The replacement of paddy with chilli in the wet and normal years decreased the number of unmet demands in the Alikota Ara area and not in Handapanagala, which highlights the fact that the diversion cannot cater to the proposed areas.

Finally, it can be concluded that WEAP software is quite suitable for analysing complex water resource systems at the initial stages of designing and also later during their management.

\section{References}

1. Loucks, D. P., \& Van Beek, E. "Water Resource System Planning and Management, An Introduction to Methods, Models and Application". UNESCO publications, 2005.

2. Karamouz, M., Houck, M. H., \& Delleur, J. W., "Optimization and Simulation of Multiple Reservoir Systems", Journal of Water Resources Planning and Management, 118(1), 1992, pp. 71-81.

3. Rani, D., \& Moreira, M. M., "Simulation Optimization Modeling: A Survey and Potential Application in Reservoir Systems Operation", Water Resource Management, 24(6), 2010, pp. 1107-1138.

4. Alfarra, A., Benedict, E. K., Hotzl, H., Sader, N. \& Sonneveld, B. "Modeling Water Supply and Demand for Effective Water Management Allocation in The Jordan Valley", Journal of Agricultural Science and Application, vol. 1, no. 1, March, 2012, pp. 1-7.

5. Hamlat, A., Errih, M. \& Guidoum, A. “Simulation of Water Resources Management Scenarios in Western Algeria Watersheds using WEAP Model", Arabian Journal of Geosciences, vol. 6, no. Issue 7, July, 2013, pp. 2225-2236.

6. Shahwan, M., Mowafy, M., Chen, B. \& Ma, Y. "Water Supply System Simulaion and Water 
Resource Management for the Gaza Strip", CSCE 2014 13th International Environmental Specialty Conference, 2014.

7. Banik, P., Tiwari, N. K. \& Ranjan, S. "Comparative Crop Water Assessment using CROPWAT", International Journal of Sustainable Materials, Processes \& ECO-efficient - IJSMPE, vol. 1, no. 3, 30 September, 2014.

8. Nazeer, M. "Simulation of Maize Crop Under Irrigated \& Rainfed Conditions with CROPWAT Model", Arpn Journal of Agricultural and Biological Science, vol. 4, no. 2, March, 2009.

9. FARAB “Technical Prefeasibility Study Report: Uma Oya Multipurpose Development Project", FARAB Energy and Water Projects, 2008.

10. Draft Report on Uma Oya Multi Purpose Development Project - Downstream Developments, Water Resources \& Project Planning Branch, Irrigation Department, Ministry of Irrigation \& Water Resources Management, Sri Lanka. 
